3. Сокращение размеров частицы в направлении движения есть сокращение длины волны фотона.

4. Сокращение течения времени при больших скоростях - это сокращение периода колебания фотона в системе «фотон-частица», т.е. увеличения частоты (энергии) фотона, требуемой для увеличения скорости системы «фотон-частица».

\title{
Tregulov V.V. \\ Properties of Raman scattering in the CdS films, formed on the monocrystalline surface and porous silicon by the chemical bath deposition method
}

Ryazan state university named for S.A. Yesenin

(Russia, Ryazan)

doi 10.18411/gq-30-11-2017-02

idsp 000001:gq-30-11-2017-02

\section{Annotation}

Raman spectra of light in CdS films formed on the surface of single-crystal and porous silicon are investigated. An explanation is offered for the nature of a wide Raman spectral line in the frequency range $220-275 \mathrm{~cm}-1$.

Key words: Porous silicon, Raman scattering, photovoltaic converter, solar cell, chemical bath deposition method.

Thin films of cadmium sulfide (CdS) made by the chemical bath deposition method can be successfully used as a window layer of photovoltaic solar cells based on p-type silicon [1]. The main advantages of the chemical bath deposition method are the ease of implementation and the possibility of forming high-quality $\mathrm{CdS}$ films on large surface areas. Recently, interest has been growing in the problem of the formation of CdS films on the surface of porous silicon in order to improve the characteristics of photovoltaic solar cells and optical sensors has been growing [2].

In this paper we present the results of studying the features of Raman scattering in $\mathrm{CdS}$ films formed by the chemical bath on the surface of single-crystal silicon (c-Si) and also on the surface of porous silicon (por-Si) layer. Raman spectra were recorded by the U-1000 spectrometer (Jobin Ivon) in standard geometry, when the laser beam and scattered light are directed along the normal to the surface of the sample. The excitation of Raman scattering in a $\mathrm{CdS}$ film was carried out by an argon laser at a wavelength of $488 \mathrm{~nm}$.

As substrates for manufacturing experimental samples, c-Si p-type conductivity plates with a specific resistance of $1 \mathrm{ohm}-\mathrm{cm}$ and a surface orientation (100) were used. Before the deposition of the CdS film or the formation of the por-Si layer, the c-Si plates were etched in aqueous $\mathrm{KOH}$ solution to obtain a textured surface relief is produced. The por-Si film was formed by anodic electrochemical etching in an electrolyte consisting of $\mathrm{HF}$ and $\mathrm{C} 2 \mathrm{H} 5 \mathrm{OH}$ (ratio 1:1), in galvanostatic mode at a current density of $18 \mathrm{~mA} / \mathrm{cm} 2$ for 10 minutes. The thickness of the por-Si film is $2.2 \mu \mathrm{m}$.

Thin films of $\mathrm{CdS}$ by precipitation from an aqueous solution containing cadmium chloride $\mathrm{CdCl} 2(0.44 \mathrm{M})$ and thiourea $\mathrm{N} 2 \mathrm{H} 4 \mathrm{CS}(0.22 \mathrm{M})$ were formed. At the beginning, a concentrated aqueous solution of ammonia $\mathrm{NH} 4 \mathrm{OH}$ was added to the $\mathrm{CdCl} 2$ solution until the precipitate formed completely dissolved, with a chemical reaction [3]:

$$
\mathrm{CdCl}_{2}+\mathrm{NH}_{4} \mathrm{OH} \rightarrow\left[\mathrm{Cd}\left(\mathrm{NH}_{3}\right)_{4}\right] \mathrm{Cl}_{2}+4 \mathrm{H}_{2} \mathrm{O} \text {. }
$$

The compound $[\mathrm{Cd}(\mathrm{NH} 3) 4] \mathrm{Cl} 2$ is not stable and dissociates to form a complex ion $[\mathrm{Cd}(\mathrm{NH} 3) 4] 2+$. Then, an aqueous solution of thiourea to the resulting solution is added. The $\mathrm{CdS}$ compound is formed due to the chemical interaction of the complex ion with sulfur ions arising upon the dissociation of thiourea [1]:

$$
[\mathrm{Cd}(\mathrm{NH} 3) 4] 2++\mathrm{S} 2-\leftrightarrow \mathrm{CdS}+4 \mathrm{NH} 3 .
$$


Subsequently, c-Si and por-Si substrates in the solution, and CdS films were grown for 20 minutes at $90^{\circ} \mathrm{C}$ were immersed.

As was established in our earlier studies [4], the most qualitative samples of CdS/c-Si heterostructures were formed under conditions when the aqueous solution obtained as a result of reaction (1) was mixed with an aqueous solution of thiourea in the range of ratios from 1:0.5 to $1: 1.2$ by volume. Therefore, in this study samples CdS/c-Si films with CdS, formed at ratios of $1: 0.5,1: 1$ and $1: 1.5$, and $\mathrm{CdS} /$ por-Si - at a ratio of $1: 1$ are investigated. The thickness of the CdS film for the samples under study did not exceed $0.40 \mu \mathrm{m}$.

The general form of the Raman spectrum in the frequency range $200-1000 \mathrm{~cm}-1$ is practically the same for all the samples under study (Fig. 1, a).

Peaks near $300 \mathrm{~cm}-1$ and $600 \mathrm{~cm}-1$ frequencies for all samples are observed, characterizing the longitudinal optical phonon modes of the first (1LO) and second (2LO) order for CdS. According to [5], the observed situation for the hexagonal wurtzite phase of $\mathrm{CdS}$ is characteristic. This conclusion by X-ray diffraction studies of $\mathrm{CdS}$ films prepared under similar conditions is also confirmed [6]. The peak at frequency $521 \mathrm{~cm}-1$ (Fig. 1, a) is the first-order spectral line of Raman for silicon and is determined by the longitudinal optical phonon mode (1LO) [7]. The third-order spectral lines (3LO) for CdS and the second order (2LO) for silicon on each other in the frequency range 900-1000 cm-1 are superimposed (Fig. 1, a). The presence of peaks associated with silicon on the Raman spectrum (Fig. 1, a) is explained by the influence of the substrate.

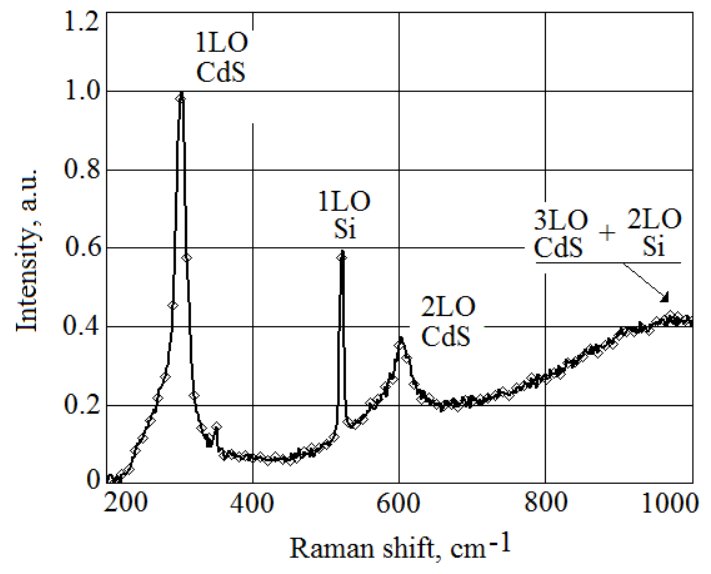

a)

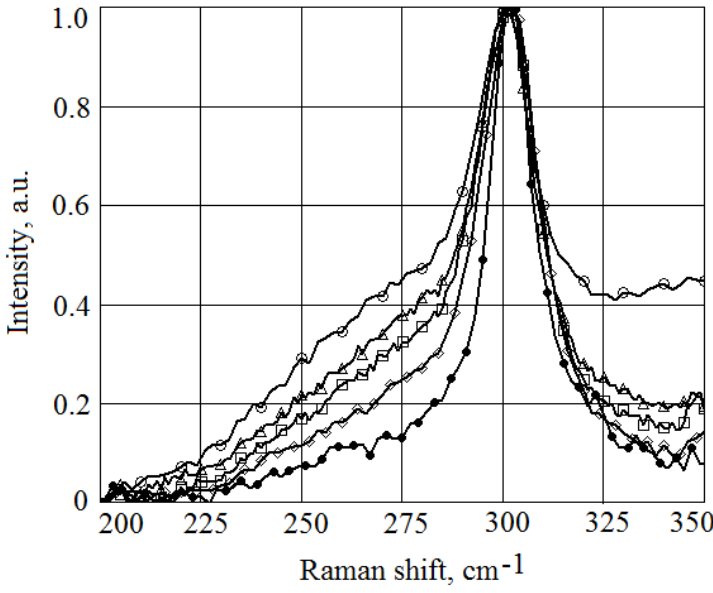

b)

Fig. 1. Raman spectra: a) typical Raman spectrum of the samples under study; b) Raman spectra of the 1LO $C d S$ line of CdS/c-Si samples prepared at the ratio of 1:0.5 (০), 1:1 ( ), 1:1.5 (4), CdS/por-Si ratios at a ratio of $1: 1$ (口), a reference sample of $\mathrm{CdS} / \mathrm{c}$-Si $(\bullet)$.

The shape of the spectral peak of the 1LO CdS film for the samples under study has significant differences (Fig. 1, b). For comparison, Fig. 1b also shows the shape of the 1LO peak of a CdS film produced by thermal vacuum evaporation on a c-Si substrate (reference sample). The CdS film of the reference sample has a polycrystalline structure. The spectral lines of the 1LO samples under study in Fig. $1 \mathrm{~b}$ have a noticeable broadening and a small shift toward low frequencies in comparison with the given line of the reference sample. This indicates that the CdS films of the test samples are formed from grains with a smaller average size compared to the reference sample [7].

On the Raman spectra of CdS films of the samples under study in the frequency range 220-275 cm-1 there is a wide structureless peak (Fig. 1, b). On the spectrum of the reference sample, this peak is not observed. According to [8], spectral bands of the Raman scattering of the compound $\mathrm{CdCl} 2$ are located in this frequency range. Cadmium chloride was used in the preparation of the test samples and was not used for the reference sample. In our work [6], using electron Auger spectrometry, it was established that CdS films formed under similar 
conditions contain an impurity of chlorine. Moreover, the most probable source of chlorine is the compound $\mathrm{CdCl} 2$, used in the manufacture of $\mathrm{CdS}$ films by the chemical bath deposition method. As follows from the analysis of the intensity of the Raman peak in the frequency range 220-275 cm-1, the largest amount of $\mathrm{CdCl} 2$ contains a $\mathrm{CdS}$ film formed at the ratio of aqueous solutions of [Cd (NH3)4] $\mathrm{Cl} 2$ and thiourea 1:0.5. The smallest content of $\mathrm{CdCl} 2$ in a $\mathrm{CdS}$ film formed at a 1:1 ratio is observed. It should be noted that the intensity of the Raman peak of the CdS film in the frequency range $220-275 \mathrm{~cm}-1$ for the CdS/por-Si sample prepared at a 1:1 solution ratio is noticeably higher than for the $\mathrm{CdS} / \mathrm{Si}$ sample prepared under similar conditions (Fig. 1, b). This can be explained by the fact that with the growth of CdS on the por-Si surface, some of the cadmium chloride is retained within the porous structure. When $\mathrm{CdS}$ is formed on the surface of $\mathrm{c}-\mathrm{Si}$, the excess of cadmium chloride is more effectively removed as a result of washing the samples.

It is important to note that a wide Raman peak in the 220-275 cm-1 frequency range was previously observed in a number of works (for example, [5]) in CdS films prepared by the chemical bath deposition method, but its nature has not been reported in the literature.

Thus, as a result of the studies carried out, an explanation of the nature of the wide Raman peak in the frequency range $220-275 \mathrm{~cm}-1$ is proposed. The nature of the dependence of the intensity of this peak on the features of technological conditions for the formation of a $\mathrm{CdS}$ film on the surface of c-Si and por-Si is established.

\section{The work was supported by the grant of the Ministry of Education and Science of the Russian Federation No. 3.9506.2017/8.9. $* * *$}

1. Mahdi M.A., Kasem S.J., Hassen J.J., Swadi A.A. Structural and optical properties of chemical deposition CdS thin films / Int. J. Nanoelectronics and Materials. - 2009. - No 2. - p. 163-172.

2. Jafarov M.A., Nassirov E.F., Jahangirova S.A. Nano-CdS/porous silicon heterojunction for solar cell / International Journal of Scientific \& Engineering Research. - 2015. - v. 6. - No 7. - p. 849 - 853.

3. Lidin R.A., Molochko V.A., Andreeva L.L. Khimicheskiye svoystva neorganicheskikh veshchestv [Chemical properties of inorganic substances] - Moscow.: Koloss, 2006. $-480 \mathrm{p}$.

4. Tregulov V.V. Optimizatsiya tekhnologii izgotovleniya geterostruktur CdS/Si(p) [Optimization of the technology of manufacturing heterostructures $\mathrm{CdS} / \mathrm{Si}(\mathrm{p})]$ / Nauchno-tekhnicheskiy vestnik Povolzhia. 2012. - No 2. - p. 31-34.

5. Oladeji I.O., Chow L., Liu J.R., Chu W.K., Bustamante A.N.P., Fredricksen C., Schulte A.F. Comparative study of CdS thin films deposited by single, continuous, and multiple dip chemical processes / Thin Solid Films. - 2000.- No. 359. - p.154-159.

6. Tregulov V.V. Issledovaniye geterostruktur $\mathrm{CdS} / \mathrm{Si}(\mathrm{p})$, izgotovlennykh metodom gidrokhimicheskogo osazhdeniya CdS [Investigation of $\mathrm{CdS} / \mathrm{Si}(\mathrm{p})$ heterostructures prepared by the hydrochemical deposition of CdS] / Vestnik RGU imeni S.A. Esenina. - 2011. - No 3(32). - p. 165 - 180.

7. Yang M., Huang D., Hao P. Study of the Raman peak shift and the linewidth of light-emitting porous Silicon / J. Appl. Phys. - 1994. - Vol. 75. - No 1. - p. 651-653.

8. Maroni V.A., Hathaway E.J. Raman spectra of the $\mathrm{CdCl} 2-\mathrm{KCl}$ system / Electrochimica Acta. - 1970. v.15. - p. $1837-1840$. 